\title{
Correction to: A short primer on lung stereology
}

\author{
Matthias Ochs ${ }^{1,2^{*}}$ (1) and Julia Schipke ${ }^{3,4}$ (B)
}

\section{Correction to:Ochs and Schipke Respiratory Research (2021) 22:305}

https://doi.org/10.1186/s12931-021-01899-2

Following publication of the original article [1], the authors identified errors in Table 3, Figure 1 and few headings style. It have been included in this correction.

The original article has been corrected.

1. Table 3 layout has been updated and given below

2. Formula in Figure 1 legend has been updated.

The total volume of type II cells, V(type II), is then obtained as

$$
\begin{aligned}
V(\text { type II })= & V(\text { lung }) \cdot V_{V}(\text { par } / \text { lung }) \cdot V_{V}(\text { alvsep } / \text { par }) \\
& \cdot V_{V}(\text { typeII } / \text { alvsep })
\end{aligned}
$$

3. Heading level has been updated with the Capital letters

Step 1: Planning your stereological study

Step 2: Preparation of lung tissue

Step 3: Definition and measurement of the reference space to the material. If material is not included in the article's Creative Commons licence and your intended use is not permitted by statutory regulation or exceeds the permitted use, you will need to obtain permission directly from the copyright holder. To view a copy of this licence, visit http://creativecommons.org/licenses/by/4.0/. The Creative Commons Public Domain Dedication waiver (http://creativeco mmons.org/publicdomain/zero/1.0/) applies to the data made available in this article, unless otherwise stated in a credit line to the data. 
Table 3 The 7 crucial steps of a stereological study of the lung

\section{Step}

1. Planning your stereological study

2. Preparation of lung tissue

3. Definition and measurement of the reference space

4. Sampling

5. Doing the measurements

6. How many counts are enough?

7. Reporting your methods and results

\section{Points to consider}

Pilot study

Target compartment

Stereological parameters

Sampling and analysis design

Route of fixation

Composition of fixative

Post-fixation and processing

Dehydration and embedding

Fixed lung volume:

- Archimedes principle

- Cavalieri estimator

Randomization of location:

- Systematic uniform random sampling

- Cascade sampling

- Stratified sampling

- Fractionator sampling

Randomization of spatial orientation

- Isotropic uniform random sections

- Vertical sections

Dimension of stereological parameter of interest

Dimension of geometric probe (test system)

Disector for number estimation

Accuracy

Precision

Coefficient of error

Total values

Ratios and inverse of ratios

Scatter plots

Standard deviation

\section{Author details}

${ }^{1}$ Institute of Functional Anatomy, Charité-Universitätsmedizin Berlin, Corporate Member of Freie Universität Berlin and Humboldt Universität Zu Berlin, Philippstr. 11, 10115 Berlin, Germany. ${ }^{2}$ German Center for Lung Research (DZL), Berlin, Germany. ${ }^{3}$ Institute of Functional and Applied Anatomy, Hannover Medical School, Hannover, Germany. ${ }^{4}$ Biomedical Research in Endstage and Obstructive Lung Disease, Member of the German Center for Lung Research (DZL), Hannover, Germany.

\section{Reference}

1. Ochs M, Schipke J. A short primer on lung stereology. Respir Res. 2021;22:305. https://doi.org/10.1186/s12931-021-01899-2.

\section{Publisher's Note}

Springer Nature remains neutral with regard to jurisdictional claims in published maps and institutional affiliations.

Published online: 08 March 2022 